\title{
Kajian Literatur Pengaruh Good Corporate Governance Terhadap Nilai Perusahaan
}

\author{
Rizky Amalia Nasution \\ Universitas Sumatera Utara \\ amalia.19kye@gmail.com
}

\begin{abstract}
Abstrak
Tulisan ini bertujuan untuk mendeskripsikan bagaimana pentingnya Good Corporate Governance dalam suatu perusahaan. metode penelitian ini menggunakan metode penelitian kualitatif dengan pendekatan kajian literatur. Sumber data penelitian adalah berupa artikel-artikel yang berkaitan dengan Good Corporate Governance. Hasil kajian literatur menunjukkan bahwa dengan Good Corporate Governance yang diterapkan dengan baik akan dapat mempengaruhi kinerja keuangan perusahaan dan nilai perusahaan dimata investor. Good Corporate Governance ada untuk mengarahkan perusahaan menjadi lebih baik dalam mengelola perusahaan. Pengelolaan perusahaan dengan baik dapat mempengaruhi nilai perusahaan dan juga kinerja perusahaan. Dengan kinerja perusahaan dan nilai perusahaan yang meningkat, maka investor percaya bahwa perusahaan dapat memenuhi kewajiban dari para pemegang saham. Dengan begitu, investor akan memiliki trust dan yakin untuk menanamkan modalnya pada perusahaan. Dengan banyaknya investor yang percaya untuk menanamkan modalnya pada perusahaan tersebut maka kegiatan operasional perusahaan juga akan lebih baik.
\end{abstract}

\section{Keywords: Good Corporate Governance, kinerja perusahaan, komite audit, nilai perusahaan, corporate value.}

\section{PENDAHULUAN}

Sebuah perusahaan pasti menginginkan siklus hidup yang panjang. Ditengah persaingan global yang semakin ketat, setiap perusahaan harus memiliki cara agar dapat bertahan hidup dan bersaing di pasar. Berdasarkan dari konsep baru dunia bisnis, sebuah perusahaan tidak hanya berorientasi pada profit, lebih dari itu, tujuan utama perusahaan adalah untuk menciptakan nilai atau value agar dapat mencapai competitive advantage (Balanescue \& Bratianu: 2008). Untuk mencapai itu semua, perusahaan harus memiliki nilai yang jelas dan kuat. Dengan meningkatnya nilai perusahaan, hal tersebut menjadi sebuah prestasi bagi perusahaan.

Nilai perusahaan merupakan nilai-nilai yang dipercaya dapat menyatukan sistem, proses dan strategi dalam mencapai tujuan jangka panjang perusahaan. Nilai suatu perusahaan tercermin dari visi dan misi perusahaan tersebut dan bagaimana percapaian atas visi dan misi tersebut. Lebih dari itu, citra perusahaan yang baik dapat mempengaruhi sebuah nilai perusahaan. 
Dimana Ketika perusahaan melakukan praktik Good Corporate Governance dengan baik, Penerapan Good Corporate Governance merupakan salah satu cara agar nilai suatu perusahaan dapat dinilai baik. Good Corporate Governance muncul sebagai akibat dari masalah dimana ada beberapa perilaku untuk mendatangkan keuntungan pribadi dengan merugikan kepentingan dari pihak lain. Dengan danya Good Corporate Governance diharapkan mampu menciptakan tata kelola perusahaan yang baik dan sehat sehingga tidak ada pihak yang diuntungkan ataupun dirugikan. Pihak yang berkaitan langsung (stakeholder) dengan perusahaan diperlakukan dengan sama. Nilai perusahaan yang tinggi menjadi keinginan para pemilik perusahaan, karena dengan nilai perusahaan yang tinggi hal tersebut menunjukkan kemakmuran pemegang saham sehingga para pemegang saham tidak ragu dalam menginvestasikan modalnya kepada perusahaan.

Di Indonesia, penerapan praktik Good Corporate Governance masih sulit untuk diterapkan. Hal ini dibuktikan dari peringkat Good Corporate Governance selalu di bawah Singapura. (Daily, 2020). Disamping sangat berpengaruh terhadap perusahaan dan investor, penerapan Good Corporate Governance yang baik sesuai aturan juga ternyata senjata yang sangat efektif untuk melawan korupsi. Hal ini juga diikuti oleh keberadaan komite Audit dan dewan komisaris independen sebagai pelaksana tata kelola.

Mekanisme dalam penerapan Good Corporate Governance antara lain adalah, dewan komisaris, komisaris independen dan komite audit. Dewan komisaris bertugas mengawasi jalannya perusahaan berdasarkan prinsip-prinsip Good Corporate Governance, selain itu juga berkewajiban dalam mengawasi kinerja direksi dan pelaksanaan dari kebijakan dari dewan direksi. Keberadaan dewan komisaris independen diharapkan sebagai pihak netral sehingga tidak ada praktik keagenan (Nathalia V Sondokan, 2019). Dengan meningkatnya jumlah anggota dewan komisaris akan meningkatkan kinerja perusahaan dan nilai perusahaan. Hal ini sesuai dengan penelitian yang dilakukan oleh Laurensia (2014) bahwa dewan komisaris independen berpengaruh positif terhadap nilai perusahaan, sebaliknya penelitian oleh N.V Sondokan (2019) bahwa dewan komisaris independen tidak berpengaruh terhadap nilai perusahaan.

Sedangkan komite audit adalah sebagai pihak yang menjembatani auditor eksternal dengan perusahaan dan juga dewan komisaris, juga diharapkan dapat membangun citra perusahaan yang baik di mata investor (publik) dalam pelaporan keuangan dan peningkatan kualitas audit. Tetapi, jumlah anggota komite audit yang terlalu banyak juga tidak baik bagi perusahaan karena ada banyak tugas dan pekerjaan yang terpecah sehingga anggota komite audit kurang focus dalam menjalankan tugasnya yang menyebabkan kinerja perusahaan buruk, yang berarti akan berdampak pada nilai perusahaan (Susanti, 2011)

Oleh karena itu, penerapan Good Corporate Governance harus dilakukan sesuai dengan peraturan dan bukan hanya sekedar formalitas, maka bukan hanya perusahaan yang akan mendapatkan dampak positifnya, tetapi juga baik bagi perekonomian Negara.

\section{Good Corporate Governance}

\section{LANDASAN TEORI}

Good Corporate Governance merupakan tata Kelola perusahaan yang baik dan sehat yang diperkenalkan oleh pemerintah Indonesia dan International Monetary Fund (IMF). Menurut Tunggal (2013), Good Corporate Governance merupakan sistem aturan yang mengelola dan mengawasi segala proses pengendalian usaha yang bertujuan untuk menaikkan nilai saham suatu perusahaan, dan juga sebagai salah satu bentuk perhatian kepada stakeholders, karyawan bahkan masyarakat sekitar.

Dari defenisi diatas, maka dapat disimpulkan bahwa Good Corporate Governance merupakan hal yang penting bagi perusahaan yang dapat berpengaruh terhadap 
keberlangsungan hidup perusahaan, hal ini penting dalam membantu perusahaa membangun citra atau kepercayaan pasar yang mendorong arus investasi internasional yang stabil dan bersifat jangka panjang.

Adapun tujuan dari penerapan Good Corporate Governance adalah sebagai berikut:

a. Memberikan nilai tambah bagi semua pihak yang bersangkutan dengan perusahaan (stakeholders)

b. Dapat meningkatkan kinerja dan daya saing dalam pasar nasional maupun internasional

c. Dapat menstimulus pertumbuhan ekonomi nasional melalui peningkatan investasi atau penanaman modal asing langsung) dalam industry infrastruktur

d. Untuk menghindari praktik bisnis yang melanggar etika bisnis, misalnya penyelewengan, pernyataan palsu, suap dan diskriminasi

e. Terciptanya hubungan dan lingkungan kerja yang kondusif dan profesionak di antara orang-orang yang ada di dalam perusahaan dan masyarakat sekitar.

Menurut Forum for Corporate Governance di Indonesia (2001) Good Corporate Governance memiliki prinsip-prinsip dasar sebagai berikut:

a) Transparency

Pemegang saham harus diberikan informasi dengan benar mengenai hak-hak-nya.

Pemegang saham juga dapat berperan ikut serat dalam pengambilan keputusan mengenai perubahan-perubahan dasar yang terjadi pada perusahaan, serta memperoleh bagian keuntungan dari perusahaan.

b) Accountability

Para pengelola memiliki kewajiban dalam membina system akuntansi yang efektif di perusahaan agar menghasilkan laporan keuangan (financial statement) yang dapat dipercaya public.

c) Responsibility

Peran para pemegang saham diakui sebagaimana yang ditetapkan oleh hukum yang berlaku dan Kerjasama yang baik antara perusahaan serat stakeholders dalam menciptakan kesejahteraan

d) Independency

Dalam menjalankan usahanya, perusahaan berusahan secara independent dan menghindari adanya praktik dominasi oleh salah satu pihak dalam perusahaan. Segala keputusan yang diambiloleh perusahaan diharapkan menjadi keputusan yang objektif dan independent tanpa campur tangan atau pengaryh dan tekanan pihak lain.

e) Fairness

Perusahaan memberikan perlakuan yang sama terhadap para pemegang saham dan stakeholder. Tidak membedakan antara pemegang saham minoritas atau pemegang saham asing. Hal ini juga berlaku bagi masyarakat, perusahaan harus memberikan kesempatan yang sama kepada masyarakat dalam proses rekrutmen tanpa melihat kondisi fisik, ras, agama, gender, dll.

Hal lain yang penting dibahas dalam Good Corporate Governance adalah komite audit. Karena komite audit memiliki peran dalam penerapan Good Corporate Governance yang baik, dimana tanggungjawab komite audit adalah memberikankepastian bahwa perusahaan telah patuh dan tunduk pada undang-undang dan peraturan yang berlaku dan juga melakukan control yang efektif terhadap konflik kepentingan yang dapat merugikan perusahaan dan menurunkan nilai perusahaan. (Maureen, 2017) 


\section{Komite Audit}

Menurut (Daniel Felimanto Hartono, 2014), komite Audit merupakan komite yang dibentuk oleh dewan komisaris yang bertanggungjawab kepada dewan komisaris dan memiliki tugas utama untuk memastikan bahwa prinsip-prinsip Good Corporate Governance diterapkan secara konsisten dan memadai.

Menurut Toha (2004) Komite audit adalah sekelompok orang yang dibentuk oleh dewan komisaris sebuat perusahaan tercatat, yang di dimana anggotanya diangkat dan diberhentikan oleh dewan komisaris perusahaan dan tugasnya melakukan pemeriksaan atau penelitian yang dianggap perlu dilakukan terhadap perusahaan.

Dari defenisi di atas, maka dapat disimpulkan bahwa komite audit adalah komite yang diangkat oleh dewan komisari suatu perusahaan yang memiliki tugas dan tanggung jawab dalam membantu dewan komisaris dalam memantau keuangan perusahaan.

Dengan defenisi tersebut, komite audit menurut effendi (2007) perlu menjalin hubungan dengan:

a. Dewan komisaris

Seperti yang tergambar pada fungsi dari komite audit yaitu membantu tugas dari dewan komisaris dalam pengendalian perusahaan, maka komite audit wajib memberikan laporan hasil tugas yang diberikan oleh dewan kimisaris dalam bentuk laporan berkala.

b. Manajemen

Komite audit berkomunikasi dengan manajemen dalam rangka meningkatkan pengendalian perusahaan. Komite audit harus berkomunikasi dengan manajemen secara signifikan, tetapi manajemen tidak diharuskan hadir dalam setiap rapat.

c. Auditor internal

Komunikasi yang terjalin antara auditor internal dengan komite audit adalah meliputi mengenai hal-hal pertanggungjawaban atas struktur kendali internasional dan laporan keuangan bebas kesalahan material, seleksi kebijakan akuntansi, estimasi akuntansi, dampak penyesuaian hasil audit, pertanggungjawaban data non keuangan yang telah disepakati bersama, ketidaksepakatan manajemen dan auditor internal, diskusi pilihan auditor eksternal, dan lainnya.

d. Auditor eksternal

Tanggungjawab komite audit adalah menilai hasil laporan audit dari auditor eksternal. Jadi komite audit memiliki kedudukan sebagai perantara dari dewan komisaris dengan kompetensi yang dimiliki, diharapkan bisa mengoptimalkan fungsi dari auditor eksternal bagi perusahaan. Hal-hal yang dikomunikasikan antara komite audit dengan auditor eksternal adalah tanggung jawab auditor berdasarkan standart auditing yang telah ditetapkan oleh Ikatan Akuntan Indonesia (IAI), kebijakan akuntansi signifikan, pertimbangan manajemen dan estimasi akuntansi, penyesuaian audit signifikan, informasi lain dalam dokumen yang berisi laporan keuangan yang telah diaudit, dan lainnya.

\section{Dewan Komisaris Independen}

Dewan Komisaris Independen merupakan hal yang penting menjalankan dalam penerapan Good Corporate Governance. Karena dengan adanya dewan komisaris Independen dalam suatu perusahaan, perusahaan diharapkan dapat mengurangi kecurangan dalam pelaporan keuangan. Selain itu, kinerja yang efektif yang dilakukan oleh dewan komisaris independen terhadap perusahaan dan shareholder akan membantu meringankan agency conflict yang akan berdampak pada nilai suatu perusahaan. (Laurensia Chintia Dewi, 2014) 


\section{Nilai Perusahaan}

Nilai perusahaan merupakan hal yang penting bagi perusahaan, terutama pada perusahaan yang sudah go public. Jika nilai perusahaan baik, maka investor akan percaya kepada perusahaan dalam menanamkan modalnya. Tidak hanya itu, dengan nilai perusahaan yang baik, hal itu berarti juga bahwa kinerja keuangan perusahaan baik yang mengisyaratkan bahwa kemakmuran dari pemegang saham juga tinggi.

Nilai suatu perusahaan dipengaruhi oleh struktur kepemilikan sebuah perusahaan tersebut, proporsi independent commissioner dan audit committee. Semakin tinggi kepemilikan saham oleh sebuah institusi, maka semakin besar pula proporsi komisaris independent dan komite audit maka semakin baik pengontrolan manajemen. Hal ini akan berdampak pada meningkatnya corporate value.

Investor menggambarkan suatu perusahaan dengan melihat dari kinerja perusahaan. Jika kinerja semakin baik maka perusahaan tersebut tidak berpotensi pailit (bangkrut), hal ini jelas akan berdampak pada saham perusahaan yang akan naik. Corporate Value diproksikan oleh harga saham dan jumlah saham yang beredar. Corporate Value juga akan meningkat seiring dengan naiknya harga saham dan jumlah saham yang beredar. (Hardianto, 2013.)

\section{METODE PENELITIAN}

Penelitian ini adalah penelitian kualitatif dengan metode kajian literatur. Menurut (Afifuddin, 2012) bahwa kajian literatur adalah alat penting yang digunakan sebagai contact review, karena sangat berguna dan membantu dalam memberikan konteks dan arti di dalam sebuah penulisan yang sedang dilakukan dan juga melalui kajian literatur ini peneliti dapat menyatakan secara eksplisit dan pembaca juga mengetahui, mengapa hal tersebut harus diteliti, baik dari segi sebjektif maupun dari sisi hubungan penelitian dengan peneltian lain yang relevan.

Menurut (Marzali, 2016) Kajian literatur adalah satu bentuk penelitian kepustakaan dengan membaca berbagai jenis buku dan jurnal, dan sejenisnya yang berkaitan dengan topik pembahasan penelitian guna untuk menghasilkan sebuah karya tulisan ilmiah, seperti skripsi, tesis, dan disertasi. Penulis mencari literatur yang sesuai dengan topik dan pembahasan penelitian, tentang masyarakat dan wilayah penelitian, tentang teori-teori yang digunakan dan dihasilkan yang berkaitan dengan topik penelitian yang akan diteliti, tentang metode penelitian yang digunakan dan seterusnya.

Kajian literatur dilakukan dengan kesadaran bahwa pengetahuan akan bertambah secara terus menerus (berakumulasi), bahwa topik dan daerah/wilayah penelitian yang akan kita lakukan sudah pernah dilakukan oleh orang sebelumnya, dan kita dapat belajar dari apa yang telah orang lain lakukan. Menurut Marzali (2016) Tujuan utama dari kajian literatur adalah kajian literatur yang dilakukan guna menulis sebuah makalah untuk memperkenalkan kajiankajian baru pada topik tertentu yang penting untuk diketahui oleh orang yang bergiat dalam bidang penelitian tersebut, dan sewaktu-waktu makalah ini dapat diterbitkan untuk kepentingan umum, kedua untuk kepentingan penelitian sendiri. Dalam hal ini peneliti membuat kajian literatur dimaksudkan untuk memperkaya wawasan peneliti tentang topik bahasan tertentu serta menolong peneliti dalam memformulasikan masalah penelitian, dan menolong peneliti dalam menentukan metode-metode dan teori yang tepat digunakan dalam penelitian tersebut. Kajian-kajian dari penelitian orang lain dapat kita gunakan sebagai literatur dalam penelitian yang akan kita lakukan, khususnya bagi mahasiswa yang akan menulis karya ilmiah.

Berdasarkan penjelasan di atas, maka peneliti menggunakan metode studi literatur mengenai topik Good Corporate Governance dan yang berkaitan dengan nilai perusahaan, komite audit, komisaris Independen dengan menganalisis jurnal-jurnal dan artikel-artikel yang terkait sebagai bahan analisis agar terlaksana artikel yang diharapkan. 


\section{PEMBAHASAN}

Nilai perusahaan dapat menggambarkan keadaan suatu perusahaan. Semakin baik nilai suatu perusahaan, maka tersebut perusahaan akan dipandang baik oleh para calon investor.

Penerapan praktik Good Corporate Governance yang baik harus diikuti oleh adanya direktur independent. Perbedaan kepentingan antara Direksi dan pemilik perusahaan sering menjadi masalah klasik yang timbul. Hal ini dapat dihindari dengan keberadaan dewan komisaris independenDimana direktur independent tersebut memiliki fungsi sebagai pihak netral yang dapat menjembatani kepentingan antara direktur perusahaan dengan shareholder. Di Indonesia sendiri, fungsi dari direktur independent masih abu-abu. Jika fungsi dari direktur independent sendiri jelas, maka hal tersebut dapat membuat penerapan Good Corporate Governance dalam perusahaan akan berjalan lebih efektif (Khameswary, 2019). Komite audit dan komisaris independent merupakan hal yang harus dan perlu untuk diperhatikan oleh pada investor karena memiliki pengaruh terhadap nilai perusahaan. semakin tinggi proporsi komisaris independent, maka nilai perusahaan akan rendah. Maka seharusnya proporsi komisaris independen yang tinggi akan mengurangi potensi adanya ekspoloriasi oleh shareholder mayoritas (pengendali), karena pada perusahaan public dewan komisaris merupakan representasi dari pubik atau shareholder minoritas. Hal ini mungkin dikarenakan keberadaan komisaris independent di Indonesia belum optimal (Akuilinus Yosephus, 2021).

Dengan diterapkannya Good Corporate Governance di suatu perusahaan dan dengan adanya komite audit maka hal tersebut berpengaruh terhadap penghindaran pajak. Dalam hal ini dijelaskan bahwa komite audit independent dalam menjalankan tugasnya melakukan pengendalian internal perusahaan serta memonitor dan mengawasi dijalankan dengan baik sehingga penghindaran pajak oleh perusahaan tidak terjadi pada perusahaan. Namun dengan adanya praktik penghindaran pajak tersebut dimata investor tidak menurunkan nilai perusahaan. Selain itu, praktik penghindaran pajak tersebut masih memenuhi aturan perpajakan (hukum) (Purba, 2020). Karena Good Corporate Governance merupakan prinsip-prinsip yang harus diterapkan oleh perusahaan untuk memaksimalkan nilai perusahaan, meningkatkan kinerja dan kontribusi perusahaan, dan juga menjaga keberlangsungan hidup perusahaan dalam jangka panjang. Perusahaan perlu dalam meningkatkan penerapan Good Corporate Governance dengan lebih baik untuk dapat meningkatkan nilai perusahaan sehingga para investor yakin dalam menanamkan modalnya pada perusahaan. (Malahayati, 2020). Penerapan Good Corporate Governance yang baik dalam era digital 4.0 tidak bisa dipisahkan dari tata Kelola perusahaan dengan teknologi informasi yang baik. Teknologi informasi bukan hanya sekedar membantu pekerjaan tetapi juga sebagai strategi bisnis dalam perusahaan, pengambilan keputusan dan pengawasan juga merupakan agenda penting yang akan dibahas pada rapat direksi dan dewan komisaris perusahaan. Tata Kelola teknologi informasi perusahaan yang baik merupakan suatu kebutuhan bisnis yang dapat mendukung tujuan perusahaan dan kebutuhan bisnis. Komite audit memiliki pengaruh dalam meningkatkan kinerja keuangan perusahaan yang berdampak pada nilai perusahaan yang baik. (Retno Ryani Kusumawati, 2021).

Dewan komisaris independent memiliki peran yang cukup besar dalam meningkatkan Return On Asset perusahaan. berdasarkan penemuan dari (Salsabila, dkk, 2017) bahwa DKI sudah memenuhi kriteria yang diterapkan dalam penerapan jumlah komisaris independen yaitu $30 \%$. Hal ini berarti jika semakin besar proporsi dewan komisaris independent yang berasal dari luar perusahaan dengan kemampuan dan pengalaman yang baik dan beragam akan menyebabkan meningkatnya kemampuan mereka dalam melakukan pengawasan. Keberadaan dewan komisaris pada perusahaan diharapkan dapat memantau dan meningkatkan dalam penerapan Good Corporate Governance. Dengan adanya dewan komisaris independent, hal ini 
secara dominan mempengaruhi nilai perusahaan, hal ini dikarenakan jumlah anggota komisaris independent pada perusahaan dapat menunjukkan indenpendensi perusahaan tersebut sehingga fungsi pengawasan dapt berjalan dengan lebih baik dan mempengaruhi nilai perusahaan. Selain itu, peran Komite audit juga penting dalam penerapan Good Corporate Governance terhadap nilai perusahaan. dimana semakin besar peran komite audit makan akan semakin baik pula kualitas laporan dr perusahaan tersebut dan pengawasan terhadap manajemen juga semakin baik karena kinerja komite audit yang efektif. Hal ini akan berdampak positif juga terhadap profitabilitas perusahaan karena komite audit dapat bekerja dengan lebih baik dalam Menyusun laporan keuangan sehingga perusahaan dapat terkontrol dengan lebih baik dan konflik keagenan dalam mensejahterakan kepentingan pribadi dapat dihindari (Salsabila Sarafina, 2017)

\section{KESIMPULAN}

Hasil yang diperoleh adalah bahwa Good Corporate Governance memiliki pengaruh dalam meningkatkan Corporate Value. Dengan penerapan Good Corporate Governance yang baik maka dapat meningkatkan nilai perusahaan. Dengan meningkatnya nilai perusahaan maka investor semakin percaya dan tidak ragu untuk menanamkan modalnya kepada perusahaan. Penerapan Good Corporate Governance yang tepat juga harus diikuti oleh adanya komite audit dan komisaris nndependen agar terciptanya perusahaan dengan sistem tata kelola yang baik. Dengan penerapan Good Corporate Governance yang baik dan efektif, akan membuat kinerja perusahaan semakin baik pula. Hal tersebut membuat perusahaan tidak berpotensi bangkrut. Hal ini jelas akan berdampak pada saham perusahaan yang akan naik. Corporate Value diproksikan oleh harga saham dan jumlah saham yang beredar. Corporate Value juga akan meningkat seiring dengan naiknya harga saham dan jumlah saham yang beredar.

\section{SARAN}

Saran bagi perusahaan adalah perlu melakukan peningkatan pada penerapan Good Corporate Governance dengan lebih baik. Karena penerapan Good Corporate Governance yang efisien akan berdampak pada meningkatnya nilai perusahaan dimata investor. Hal ini akan menguntungkan perusahaan dalam segi keuangan dan pendanaan.

Juga diperlukan sorang direktur independent yang benar-benar berfungsi sebagai pihak netral antara direktur perusahaan dan investor. Dan juga disarankan untuk para investor untuk memperhatikan penerapan Good Corporate Governance yang baik pada perusahaan sebelum menanamkan modalnya pada perusahaan tersebut.

\section{UCAPAN TERIMAKASIH}

Saya ucapkan terimakasih kepada Allah SWT yang telah memberikan rahmat kesehatan kepada saya sehingga saya bisa menyelesaikan artikel ini. Terima kasih juga tidak lupa saya sampaikan kepada orangtua saya dan saudara-saudara saya karena kasih sayang yang mereka berikan. Dan tidak lupa juga terima kasih yang banyak kepada para editor yang telah berkenan dan sabar dalam me-review artikel saya.Dan juga terimakasih yang banyak kepada dosen Manajemen Keuangan yang telah memberikan saya pengetahuan sehingga artikel ini dapat di tulis dan teman-teman seperjuangan yang telah memberikan dukungan.

\section{REFERENSI}

A, T. (2004). Efektivitas Peranan Komite Audit Dalam Mewujudkan GoodCorporate Governance Studi Kasus Pada PT Bank Negara Indonesia (Persero) Tbk. Kajian Ekonomi danKeuangan, Vol. 8 No. 3, September, 17-41. 
Afifuddin. (2012). Metodologi Penelitian Kualitatif. Bandung: Pustaka Setia.

Akuilinus Yosephus, R. I. (2021). Good Corporate Governance Terhadap Nilai Perusahaan . Journal Riset Mahasiswa (JRMM)Volume: 6, Nomor: 2, 1-6.

Constantin Bratianu, G. V. (2008). Vision, Mission and Corporate Values. A Comparative Anaysis of the Top 50 US Companies. Management \& Marketing (2008) Vol. 3, No. 3, pp.19-38.

Daniel Felimanto Hartono, Y. W. (2014). Pengaruh Mekanisme Corporate Governance Terhadap Kinerja Keuangan Perusahaan Perbankan. Dinamika Akuntansi, Keuangan dan Perbankan, Nopember 2014, 191 - 205.

Effendy, M. (2007). Komunikasi Komite Audit: Antara Harapan dan Kenyataan. Media Akuntansi, JuliAgustus, 65-68.

Hardianto, M. L. (2013.). Analisis Pengaruh Kinerja Keuangan terhadap Nilai Perusahaan dengan Pengungkapan CSR dan GCG Sebagai Variabel Pemoderasi (Studi Empiris Pada Perusahaan Cansumer Goods) yang Terdaftar di Bursa Efek Indonesia 20082011). Skripsi Fakultas Ekonomi UNDIP. Semarang.

Irham, F. (2011). Analisis Kinerja Keuangan Panduan bagi akademisi, manajer, dan investor untuk menilai dan menganalisis bisnis dari aspek keuangan. Bandung: Alfabeta.

Laurensia Chintia Dewi, Y. W. (2014). Pengaruh Struktur Kepemilikan dan Dewan Komisaris Independen Terhadap Nilai Perusahaan. Kinerja, Volume 18, No.1, 64-80.

Khameswary, I. K. (2019). Good Corporate Governance dan Kurang Efektifnya Direktur Independen di Indonesia. Jurnal Gema Keadilan (ISSN: 0852-011), Volume 6, Edisi II, Agustus 2019, 114-136.

Mahubessy, V. J. (2021). Good Corporate Governance, Kepailitan dan Nilai Perusahaan Pertambangan yang Terdaftar di Bursa Efek Indonesia. E-Jurnal Akuntansi Vol 31 januari 2021,142-151.

Malahayati, R. (februari 2020). Analisis Penerapan Good Corporate Governance Pada PT. Bank Aceh Syariah Cabang Kutacane. Jurnal Akuntansi dan Keuangan, Volume 8 Nomor 1, 21-30.

Marzali. (2016). Menulis Kajian Literatur. Jurnal Etnosia, 1(2), 27-36.

Maureen, M. (2017). Pengaruh Good Corporate Governance dan Corporate Social responsibility Terhadap Nilai Perusahaan. Konferensi Ilmiah Akuntansi IV 2-3 Maret 2017.

Nathalia V Sondokan, R. A. (2019). Pengaruh Dewan Komisaris independen, Dewan Direksi, dan Komite Audit terhadap Nilai Perusahaan yang Terdaftar di Bursa Efek Indonesia Periode 2014-2017. Jurnal Emba Vol.7 No.4, 5821-530. 
Purba, R. C. (2020). Pengaruh Good Corporate Governance dan Ukuran perusahaan terhadap Profitabilitas pada Perbankan yang Terdaftar di BEI. Jurnal Darma Agung Volume 28, Nomor 2, $231-238$.

Retno Ryani Kusumawati, I. S. (2021). The Effect of Good Corporate Governance on Financial performance and Corporate Value in Era 4.0 and Society 5.0. Call for Paper - 2nd International Seminar on Accounting Society "The Impact of Artificial Intelligence on Accounting for Society 5.0”, 157-164.

Salsabila Sarafina, M. S. (2017). Pengaruh Good Corporate Governance Terhadap Kinerja Keuangan dan Nilai Perusahaan (Studi Pada Badan Usaha Milik Negara (BUMN) yang Terdaftar di Bursa Efek Indonesia Periode 2012-2015. Jurnal Administrasi Bisnis (JAB)Vol. 50 No. 3 September 2017, 108-117.

Tunggal, A. W. (2013). The Fraud Audit: Mencegah dan Mendeteksi Kecurangan Akuntansi. Jakarta: Harvarindo.

(FCGI), F. f. (2021, may 1). Peranan Dewan Komisaris dan Komite Audit dalam Pelaksanaan Corporate Governance. Retrieved from fcgi: http://www.fcgi.or.id/corporategovernance/articles.html. 